\title{
Eğitim Programı Tasarımı Tercihlerine Yönelik Öğretmen Görüşleri
}

\section{Teachers' Views On Their Preferences Regarding Curriculum Design Orientation}

\author{
Serkan ÜNSAL* Fahrettin KORKMAZ**
}

\begin{abstract}
Öz: $\mathrm{Bu}$ araştırma, öğretmenlerin eğitim programı tasarım tercihlerini bazı değişkenler açısından incelemeyi amaçlamaktadır. Araştırma 2015- 2016 eğitim-öğretim yılı ikinci döneminde Hatay ilinde gerçekleştirilmiştir. Araştırmanın örneklemi ise ilkokul, ortaokul ve liselerde görev yapan 292 öğretmenden oluşmaktadır. Araştırmada veri toplama aracı olarak Baş (2013) tarafindan geliştirilen; "Eğitim Programı Tasarım Yaklaşımı Tercih Ölçeği" kullanılmıştır. Ölçek 30 madde ve 3 faktörden oluşmaktadır. Bu faktörler konu merkezli tasarım, sorun merkezli tasarım ve öğrenci merkezli tasarım şeklindedir. Veri çözümlemede aritmetik ortalama $(\bar{x})$ parametrik testlerden bağımsız örneklem t- testi ve tek yönlü varyans analizinden yararlanılmıştır. Araştırma bulgularına göre; öğretmenlerin eğitim programı tasarımı tercihlerinin öğrenci ve sorun merkezli olduğu sonucuna ulaşılmıştır. Öğretmen görüşlerinin cinsiyet, eğitim durumu, görev yapılan okul kademesi değişkenine göre farklılaşmadığı; mesleki kıdem değişkenine göre ise anlamlı düzeyde farklılaştı̆̆ tespit edilmiştir. 20 yıl ve üzeri mesleki kıdeme sahip öğretmenlere hizmet içi eğitim kursları düzenlenerek öğrenci ve sorun merkezli program tasarımının etkili bir öğrenme sürecindeki rolüne yönelik farkındalık kazandırılabilir.
\end{abstract}

Anahtar Kelimeler: Eğitim programı, program tasarımı, program tasarım yaklaşımları

\begin{abstract}
The present study aims to investigate teachers' views on their curriculum design orientation preferences in terms of some variables. The study was conducted in the province of Hatay during the academic year of 2015 and 2016. The sample consisted of 292 primary, secondary and high school teachers. This research has employed the "Curriculum Design Orientations Preference Scale" developed by Baş (2013). The tool contains 30 items and 3 factors which are subject-centred curriculum design orientation, problem centred curriculum design orientation and student-centred curriculum design orientation. Research data have been analysed via arithmetic mean $(\bar{x})$, independent samples t-test and one-way Anova. As a result of the study, teachers respond to the curriculum design orientations preferences scale as regards: "agree" in the student-centred curriculum design orientation, "neutral" in the subject-centred curriculum design orientation and "agree" in the problem-centred curriculum design orientation. A difference has been determined across gender, educational status, and occupational seniority while their views differ depending on school type.
\end{abstract}

Key words: Education curriculum, curriculum design, curriculum design orientations

\section{Giriş}

Eğitim, bireyin davranışında kendi yaşantısı yoluyla ve kasıtlı olarak istendik değişim meydana getirme sürecidir. Söz konusu istendik durum, eğitim yoluyla yapılacak değişikliklerin belli bir şekilde tasarlanmasını zorunlu kılmaktadır (Ertürk, 1982). Eğitimin etkili, verimli olması, toplumun ve bireyin ihtiyaçlarına/beklentilerine cevap vermesi, belli bir plan ve program çerçevesinde yürütülmesini gerektirmektedir. Eğitimin belli bir plan dâhilinde yürütülmesi ise akla ilk olarak eğitim programını getirmektedir (Küçüktepe, 2011). Varış'a (1996) göre eğitim programı; bir eğitim kurumunun, çocuk, genç ve yetişkinler için sağladığı tüm faaliyetleri; Aydıner'e (2015) göre ise Yunanca'dan gelen bir kavram olup yapılacak bir işin bölümleri, bölümlerin sırası ve zamanını gösteren tasarıların tümü olarak tanımlamaktadır.

*Yrd. Doç. Dr., Kahramanmaraş Sütçü İmam Üniversitesi, Eğitim Bilimleri Fakültesi, e-posta. serkan unsa109@hotmail.com

**Dr. Milli Eğitim Bakanlığ1,korkmaz2725@gmail.com 
Eğitim programının dinamik ve değişken bir yapıda olduğu, değişen şartlar ve programdaki eksikliklerden dolayı sürekli geliştirilip/düzenlenmesi gerektiği birçok uzman tarafından vurgulanmaktadır (Erden, 1993; Aykaç, 2014; Demirel, 2011). Yine Marsh (2004) çağımızdaki hızlı değişime dikkat çekmekte ve bu değişimden eğitimdeki hedeflerin, içeriğin, öğretim stratejilerinin ve değerlendirme sürecinin önemli derecede etkilendiğini ifade etmektedir. Bu bağlamda eğitim programlarının ihtiyaçlar doğrultusunda sürekli revize edilmesi program geliştirme kavramının gündeme getirmektedir. Program geliştirme; eğitim programının hedef, içerik, öğrenme-öğretme süreci ve değerlendirme öğeleri arasındaki dinamik ilişkiler bütünü olarak tanımlanmaktadır (Demirel, 2011). Program geliştirmeyi Akkoyunlu, Altun ve Soylu (2008) ise neyin öğretileceğine karar verme süreci olarak tanımlarken; program geliştirme sürecinin öncelikli olarak denence niteliğinde olduğunu ifade eden Ertürk (1982) program geliştirme sürecinin tasarlama-deneme-değerlendirme ve düzeltme aşamalarından sonra yaygınlık kazanacağını ifade etmektedir. Aydıner (2015) tarafından en genel anlamıyla program geliştirme, eğitim programlarının tasarlanması, uygulanması, değerlendirilmesi ve veriler doğrultusunda yeniden düzenlenmesi şeklinde ifade edilmektedir. Program geliştirme sürecinin ilk aşaması program çalışma planı hazırlanarak ihtiyaç analizinin yapıldığı planlama aşaması; ikinci aşaması hedeflerin belirlenmesi ve hedeflere yönelik içerik seçimi/düzenlemesi, öğrenme yaşantılarının, ölçme değerlendirme araçlarının belirlendiği tasarlama aşaması; üçüncü aşaması, programın pilot taslağının uygulandığ 1 deneme aşaması; dördüncü aşaması pilot uygulamalardaki dönütler çerçevesinde eksiklik/aksaklıkları değerlendirme aşaması; beşinci aşamasının gerekli eksikliklerin telafi edildiği düzeltme aşaması; son aşaması ise düzeltme sonunda programların tüm ülkede uygulanmasını öngören yaygınlaştırma aşaması olduğunu ifade edilmektedir (Küçüktepe, 2012).

Eğitim programı tasarımı, bir programın hangi öğelerden oluşacağının ortaya çıkarılması ve buradan hareketle öğretimin düzenlenmesini belli bir bütünlük içerisinde ele almayı amaçlar (Demirel, 2011; Alc1, 2012). Yine eğitim programı tasarımı Ornstein ve Hunkins'a (2014) göre, programın dört temel öğesi olan; hedef, içerik, öğrenme yaşantıları ve değerlendirme sürecini ifade etmektedir. Eğitim programı tasarımı Aykaç'a (2014) göre bir yandan programın hangi öğelerden oluşacağ 1 diğer yandan bu öğeler arasında nasıl bir ilişki kurulacağına karar verme sürecidir. Bundan dolayı eğitim programı planlanırken işe öncelikle programın nasıl olacağının tasarlanmasıyla başlanmalıdır. Eğitim programı tasarımı, eğitim programının ana çerçevesinin ortaya konulmasında önemli bir yere sahiptir. Bu bağlamda program tasarımcıları tarafından ortaya konulan programların; bireyin, toplumun ve aynı zamanda konu alanının ihtiyaçlarına cevap verebilecek nitelikte olması gerekmektedir.

Eğitim sürecinde belirlenen hedeflerin gerçekleştirilmesinde öğretim programının iyi bir şekilde tasarlanmasının önemini vurgulayan Çeliköz (2004) planlamanın ayrıntılı bir şekilde yapılması ile amaçların istenilen düzeyde gerçekleşmesi arasındaki pozitif ilişki olduğunu ifade etmektedir. Yine bu bağlamda Türkiye'de program geliştirme sürecinin ilk aşamasında planlama aşaması yer almaktadır.

Bir programı tasarlarken Ornstein ve Hunkins'a (2014) göre karar verilen tasarımın bireylerin temel inançları, neyi nasıl öğrendikleri, edinilen bilgileri nasıl kullanacaklarını belirleyebilmek için felsefe ve öğrenme teorileri dikkate alınmalıdır. Yeni bir program tasarlarken öğeler arasındaki bağlantıların nasıl kurulacağı, öğelerin düzenlenmesi program tasarımının temelini oluşturmaktadır.

Eğitim programı geliştirme sürecinde planlama aşamasında ilk yapılması gereken programın nasıl olması gerektiğine; yani program tasarımına karar verilmesi aşamasıdır. $\mathrm{Bu}$ karar verme sürecinde programın hangi öğelerden oluşacağı, öğelerin birbirleriyle ilişkisinin nasıl olacağ1, hangi öğelerin ön planda tutulacağ 1 gibi birçok faktör göz önünde bulundurulmalıdır (Demirel, 2011; Alc1, 2012; Aykaç, 2014). Program tasarımında yanıtlanması gereken dört temel soru bulunmaktadır: $\mathrm{Ne}$ yapılmalıdır? Hangi konu alanları eğitim programına dâhil edilmelidir? Hangi öğretim stratejileri işe koşulmalıdır? Programın sonuçlarını değerlendirmek için hangi ölçme araçları kullanılmalıdır? Program tasarımı felsefi ve teorik alanın yanı sıra uygulamayı da kapsamaktadır. Hedeflerin seçimi/düzenlenmesi, içeriğin nasıl 
sunulacağı ve programın etkiliğinin nasıl değerlendirileceğine ilişkin alınan kararlar ile program tasarımı arasında yakın ilişki bulunmaktadır. Yine programı tasarımlarken toplumsal ve siyasi durumlar göz önünde bulundurulmalıdır (Ornstein ve Hunkins, 2014).

Programın nasıl tasarlanacağı hususunda uzmanlar arasında farklılıklar bulunmaktadır. Eğitim programı tasarımlanırken nelerin merkeze alınacağı programı tasarlayan uzmanların benimsedikleri program yaklaşımları/modellere göre farklılık göstermektedir. Eğitim program tasarım yaklaşımları/modelleri; konu merkezli, öğrenci/çocuk merkezli ve toplum/sorun merkezli olmak üzere üçe ayrılmaktadır (Aykaç, 2014; Sönmez, 2012; Alc1, 2012). Konu merkezli tasarım modelinde, içerik merkezde olup; kazanımların içeriğe göre düzenlenmesi gerekmektedir. Konu merkezli tasarım modeli; konu tasarımı, disiplin tasarımı, geniş alanlar tasarımı, ilişkisel tasarım ve süreç tasarımlarını kapsamaktadır. Öğrenci/çocuk merkezli tasarım modeli; programın merkezinde öğrencinin olması gerektiğini vurgular. Söz konusu tasarım modeli; çocuk merkezli tasarım, yaşantı merkezli tasarım, romantik (radikal) tasarım ve hümanistik tasarımlardan oluşmaktadır. Problem/sorun merkezli tasarım modeli ise; bireyin ve toplumun yaşadığı gerçek yaşam problemlerine odaklanmaktadır. Tasarım modeli; yaşam şartları tasarımı, çekirdek tasarım, toplumsal sorun/yeniden kurmacı tasarımı kapsamaktadır (Ornstein ve Hunkins, 2014; Demirel, 2011; Aykaç, 2014).

Konu merkezli tasarım modeli Sönmez’e (2012) göre konuları/içeriği ön planda tutan ve kazanımların içeriğe göre düzenlenmesini amaçlayan bir yaklaşımdır. Yine Alc1 (2012)'ya göre konu merkezli tasarım modeli tasarım modelleri içerisinde en fazla kullanılan tasarım yaklaşımıdır. Yine en fazla sınıflama bu yaklaşım tasarımında bulunmakta olup; en eski ve iyi bilinen tasarım yaklaşımıdır. Ornstein ve Hunkins'a (2014) göre konu merkezli tasarımda konular aşamalılık ilkesi çerçevesinde basitten karmaşı̆̆a doğru düzenlenir ve öğretim süreci ders kitabındaki konuların doğrudan anlatımı veya öğrencinin konuları ezberlemesi şeklinde gerçekleşmektedir. Öğrenci/çocuk merkezli tasarım yaklaşımı ise Demirel'e (2011) göre öğrencinin programın merkezinde olduğu bir tasarımdır. Öğrencinin ilgi, ihtiyaçları ve beklentilerinin ön planda tutulduğu modelde öğrencinin en iyi şekilde nasıl öğrenebileceği üzerine odaklanılır. Ornstein ve Hunkins (2014)'a göre öğrenci merkezli tasarım, konu merkezli tasarıma tepki olarak ortaya çıkmıştır. Problem/sorun merkezli tasarım modeli Sönmez'e (2012) göre yaşamın devamlı bir değişim içinde olduğu; kişinin bu değişime uyum sağlayacak ve bu değişime yön verecek şekilde yetiştirilmesini savunan bir tasarım modelidir. Problem merkezli tasarım modeli hem bireysel hem de toplumsal sorunların çözümüne yönelik bir tasarım modelidir (Alc1, 2012; Aykaç, 2014).

Eğitim program tasarımı, eğitim programının değerlendirilmesi aşamasında da önemli rol oynamaktadır. Ertürk (1982) program değerlendirme yaklaşımlarını altı grupta toplamıştır. Bunlar; 1. Program tasarısına bakarak, 2. Ortama bakarak, 3. Başarıya bakarak, 4. Erişiye bakarak, 5. Öğrenmeye bakarak 6. Ürüne bakarak yapılan değerlendirmelerdir. Yine Demirel (2011) tarafından geliştirilen "Analitik Değerlendirme Modeli"nde program değerlendirme süreci programla ilgili yazılı materyaller ve programdan etkilenen paydaşların görüşü alınarak gerçekleştirilir.

Öğretmenlerin hangi program tasarım yaklaşımını tercih ettiklerinin belirlenmesi, Baş'a (2013) göre öğretmenlerin sınıf içi davranışlarının yanı sıra uygulamalarını, tercihlerini ve eğitim programlarından beklentilerini de ortaya koyması açısından önemlidir. Yine eğitim program tasarımı, öğretmenlerin eğitim programından beklentisi, eğitim tercihleri ve öğretim sürecine yönelik bakış açılarının belirlenmesi açısından da önemli görülmektedir. Türkiye'de 2005-2006 eğitim öğretim yılından itibaren eğitim programları öğrenci merkezli modelin ön planda olduğu yapılandırmacılık eğitim anlayışına göre düzenlenmiştir. $\mathrm{Bu}$ bağlamda yapılandırmacı eğitim anlayışında öğretmenlerin daha çok öğrenci merkezli program tasarımını tercih etmeleri beklenmektedir. Öğretmenlerin program yaklaşımlarından hangisini tercih ettiklerinin ortaya çıkarılması, uygulanmakta olan eğitim programlarına ilişkin bir bakış açısı sunması açısından da bir takım çıkarımlarda bulunma imkanı sunacağı düşünülmektedir. Ancak alan yazın incelendiğinde öğretmenlerin program tasarımı tercihlerini belirlemeye yönelik bir 
çalışmaya rastlanmamıştır. Çalışma literatüre bu bağlamda katkı sağlaması açısından önemli görülmektedir.

$\mathrm{Bu}$ çalışma; öğretmenlerin hangi program tasarım yaklaşımını tercih ettiklerini bazı değişkenler açısından incelemeyi amaçlamaktadır. Bu amaç doğrultusunda aşağıdaki sorulara cevap aranacaktır.

Araştırmanın Alt Problemleri

1. Öğretmenlerin öğrenci merkezli tasarım faktörüne ilişkin görüşleri nelerdir?

2. Öğretmenlerin konu merkezli tasarım faktörüne ilişkin görüşleri nelerdir?

3. Öğretmenlerin sorun merkezli tasarım faktörüne ilişkin görüşleri nelerdir?

4. Öğretmenlerin;

a) Cinsiyete göre,

b) Eğitim durumuna göre,

c) Mesleki kıdeme göre,

d) Çalış1lan okul kademesine göre eğitim programı tasarım yaklaşımı tercihleri açısından anlamlı bir farklılık göstermekte midir?

\section{Yöntem}

$\mathrm{Bu}$ bölümde araştırmanın modeli, veri toplama araçları ve verilerin analizine ilişkin bilgiler verilmişstir.

\section{Araştırmanın Deseni}

Araştırma betimsel bir çalışma olup tarama modelindedir. Karasar'a (2000) göre tarama (survey) modeli herhangi bir grubun geçmişte veya mevcut durumunu var olduğu şekliyle betimlemeyi amaçlayan araştırma yaklaşımıdır. Bu araştırmada öğretmenlerin eğitim programı tasarım yaklaşımı tercihlerine ilişkin görüşlerinin cinsiyet, eğitim durumu, mesleki kıdem çalışılan okul kademesi değişkenlerine göre farklılık gösterip göstermediği ortaya konulmaya çalışılmıştır.

\section{Evren ve Örneklem}

Çalışmanın evrenini Hatay ilinde görev yapan öğretmenler oluşturmaktadır. Araştırmanın örneklemini ise tesadüfî örnekleme yoluyla seçilen 292 öğretmen oluşturmaktadır. Araştırmada örnekleme yöntemi olarak "basit rastlantısal (tesadüfi) örnekleme yöntemi" seçilmiştir. Bu yöntemde evrendeki her birimin örnekleme seçilmede eşit seçilme şansına sahiptir (Balcı, 2001; Karasar, 2012). Katılımcılara ait demografik bilgiler Tablo 1' de sunulmuştur.

Tablo 1. Araştırmaya Katılan Öğretmenlerin Demografik Özellikleri

\begin{tabular}{llll}
\hline Demografik Özellikler & $\mathrm{N}$ & $\%$ \\
\hline \multirow{3}{*}{ Cinsiyet } & Erkek & 173 & 59.2 \\
& Kadın & 119 & 40.8 \\
& Toplam & 292 & 100 \\
& Lisans & 255 & 87.3 \\
Eğitim Durumu & Lisans Üstü & 37 & 12.7 \\
& Toplam & 292 & 100 \\
& $0-5 y 11$ & 94 & 32.2 \\
Mesleki Kıdem & 6-10yıl & 71 & 24.3 \\
& $11-15 y 11$ & 49 & 16.8 \\
& 16-20yıl & 46 & 15.8 \\
Okul Kademesi & 32 & 11.0 \\
& 20 Y1l ve Üzeri & 292 & 100 \\
& Toplam & 77 & 26.4 \\
Topokul & Ortaokul & 125 & 42.8 \\
& Lise & 90 & 30.8 \\
\hline
\end{tabular}


Tablo 1 incelendiğinde araştırmaya katılan öğretmenlerin 173 (\%59.2)'ü erkek; 119 (\%40.8)'u kadındır. Öğretmenlerin eğitim durumu 255 (\%87.3)'i lisans mezunu iken; 37 (\% 12.7)'si lisansüstü mezunudur. Araştırmaya katılan öğretmenlerin 94 (\%32.2)'ü 1-5 yıl; 71 (\%24.3)'i 6-10 y1l; 49 (\%16.8)'u 11-15 yıl; 46 (\%15.8)'s1 $16-20$ ve 32 (\% 11)'si ise 20 y1l ve üzeri mesleki kıdeme sahiptir. Öğretmenlerin çalıştıkları okul kademesine göre 77 (\%26.4)'si ilkokul; 125 (\% 42.8)'i ortaokul; 90 (\%30)'1 lisede görev yapmaktadır.

\section{Veri Toplama Aract}

Uygulanan anketin ilk bölümü "Kişisel Bilgi Formu" ndan oluşmakta ve cinsiyet, eğitim durumu, mesleki kıdem ve çalışılan okul kademesi değişkenlerini içermektedir. Araştırmada veri toplama aracı olarak Baş (2013) tarafından geliştirilen; "Eğitim Programı Tasarım Yaklaşımı Tercih Ölçeği” kullanılmıştır. Ölçek konu merkezli tasarım, sorun merkezli tasarım, öğrenci merkezli tasarım şeklinde üç faktörden oluşmaktadır. Ölçeğin konu merkezli tasarım boyutunda 10, sorun merkezli tasarım boyutunda 10, öğrenci merkezli tasarım boyutunda 10 toplamda ise 30 madde bulunmaktadır. Açılanan varyans konu merkezli tasarım için \%19.9; öğrenci merkezli tasarım için \%18.3; sorun merkezli tasarım \%13.7 ölçeğin tamamı için ise $\% 52$ 'dir.

Ölçeğin güvenirlik katsayıları $(\alpha)$; konu merkezli tasarım faktörü için .89; öğrenci merkezli tasarım boyutu için .89; sorun merkezli tasarım faktörü için .87; ölçeğin tamamı için ise .94 olarak hesaplanmıştır. Bu araştırma için güvenirlik katsayıları $(\alpha)$ ise konu merkezli tasarım faktörü için .86; öğrenci merkezli tasarım boyutu için .84; sorun merkezli tasarım faktörü için .80; ölçeğin tamamı için ise .89 olarak hesaplanmıştır. Araştırmaya katılan öğretmenlerden beşli likert tipinde derecelendirilen anket maddelerindeki kesinlikle katılmıyorum, katılmıyorum, kararsızım, katılıyorum, kesinlikle katılıyorum seçeneklerinden birini işaretleme yaparak görüş belirtmeleri istenmiştir (Kayhaoğlu ve Yangın, 2007). Öğretmenlerinin eğitim programı tasarım yaklaşımı tercihlerine ilişkin görüşlerinin değerlendirilmesinde göz önünde bulundurulan sinırlar Tablo 2'de sunulmuştur.

Tablo 2. Öğretmenlerinin Ĕ̈itim Programı Tasarım Yaklaşım Tercihlerine İlişkin Görüşlerinin Değerlendirilmesinde Göz Önünde Bulundurulan Sinırlar

\begin{tabular}{cll}
\hline Ağırlık & Seçenek & Sinırlar \\
\hline 1 & Kesinlikle katılmıyorum & $1.00-1.79$ \\
2 & Katılmıyorum & $1.80-2.59$ \\
3 & Kararsızım & $2.60-3.39$ \\
4 & Katıllyorum & $3.40-4.19$ \\
5 & Kesinlikle katıllyorum & $4.20-5.00$ \\
\hline
\end{tabular}

\section{Veri analizi}

Ölçek öncelikli olarak 330 öğretmene dağıtılmıştır. 300 öğretmenden geri dönüş sağlanmıştır. Ancak ölçekteki maddeleri eksik dolduran, kişisel bilgileri doldurmayan, bir maddeye birden fazla cevap veren 9 veri çalışmadan çıkarılmıştır. 292 öğretmenden elde edilen veriler SPSS 21.0 istatistiksel paket programına kodlanmış ve analizler bu veriler üzerinden yapılmıştır. Verilerin normal dağılım gösterip göstermediğini test etmek için Kolmogrov Smirnov testi kullanılmıştır. Bu işlem bağımsız değişkenlerin her bir düzeyinde normal dağılıp dağılmadığına ilişkin olarak gerçekleştirilmiştir. Test sonuçlarına göre araştırmaya katılan öğretmenlerin program tasarımı tercihlerine ilişkin görüşlerinden elde edilen puanlarının, $\mathrm{p}>.05$ 'ten büyük olması nedeniyle, normal dağılım gösterdiğine karar verilmiştir. bağımsız değişkenlerin her bir düzeyinde normal dağılıp dağılmadığına ilişkin normallik testleri işe koşulmalıdır Verilerin analizinde aritmetik ortalama $(\bar{x})$, parametrik testlerden; bağımsız örneklem t- testi, tek yönlü varyans analizi tekniklerinden yararlanılmıştır. Ayrıca anova tekniğinde anlamlı farklılık bulunduğundan, bu farklılığın hangi gruplar arasında oluştuğunu görebilmek için Lsd testi 
kullanılmıştır. Lsd testi kullanma gerekçesi tukey ve scheffe testi gibi diğer testlere göre gruplar arasında en küçük farka daha duyarlı olmasından dolayıdır (Can, 2014).

\section{Bulgular}

Araştırmanın bu bölümünde araştırmanın problemlerine ilişkin elde edilen bulgulara yer verilmiş̧ir.

\section{Öğrenci Merkezli Tasarım Faktörüne İlişkin Bulgular}

Araştırmanın birinci alt problemi "Öğretmenlerin öğrenci merkezli tasarım faktörüne ilişkin görüşleri nelerdir?” şeklinde belirlenmiştir. Yapılan çalışmada öğretmenlerin öğrenci merkezli tasarım yaklaşımına ilişkin görüşlerinin aritmetik ortalama ve standart sapma değerleri Tablo 3 'te sunulmuştur.

Tablo 3. Öğrenci Merkezli Tasarım Faktörüne İlişkin Aritmetik Ortalama ve Standart Sapma Sonuçlarl

\begin{tabular}{|c|c|c|c|}
\hline Maddeler & $\mathrm{N}$ & $\bar{x}$ & $\mathrm{~S}$ \\
\hline $\begin{array}{l}\text { M1-Derste çoğunlukla problem çözme yöntemi } \\
\text { kullanılmalıdır. }\end{array}$ & 292 & 3.93 & .960 \\
\hline $\begin{array}{l}\text { M2-Derste öğretmenden daha ziyade öğrenciler aktif } \\
\text { olmalıdır }\end{array}$ & 292 & 4.23 & .891 \\
\hline $\begin{array}{l}\text { M3-Derste, öğrencinin ilgi, ihtiyaç ve beklentileri } \\
\text { dikkate alınmalıdır. }\end{array}$ & 292 & 4.56 & .712 \\
\hline $\begin{array}{l}\text { M6- Programlarda, eğitim durumları öğesi daha fazla } \\
\text { ön plana çıkarılmalıdır }\end{array}$ & 292 & 4.01 & .909 \\
\hline $\begin{array}{l}\text { M7- Derste, önemli olan şey öğrencilerin bilgiyi } \\
\text { oluşturmaları ve yaşam durumlarına transfer } \\
\text { etmeleridir }\end{array}$ & 292 & 4.45 & .728 \\
\hline $\begin{array}{l}\text { M8- Öğrencinin kendi gözlemleri ve yaşantısıyla } \\
\text { öğrenme çabası içine girmesi önemlidir }\end{array}$ & 292 & 4.50 & .660 \\
\hline $\begin{array}{l}\text { M9-Derste bireysel çalışmalardan daha ziyade } \\
\text { işbirlikli çalışmalara yer verilmesi önemlidir. }\end{array}$ & 292 & 4.09 & .858 \\
\hline $\begin{array}{l}\text { M11-Programlar, bireysel farklılıkları gözeten bir } \\
\text { şekilde düzenlenmelidir. }\end{array}$ & 292 & 4.29 & .817 \\
\hline $\begin{array}{l}\text { M12- Okul, hayata hazırlık yeri olmaktan öte, hayatın } \\
\text { bizzat kendisi olmalıdır. }\end{array}$ & 292 & 4.32 & .796 \\
\hline $\begin{array}{l}\text { M24- Öğrencilerin kendilerini } \\
\text { gerçekleştirebilecekleri, bask1 ve zorlamanın } \\
\text { olmadığı eğitim ortamları önemlidir }\end{array}$ & 292 & 4.03 & 1.12 \\
\hline Genel Ortalama & 292 & 4.24 & .420 \\
\hline
\end{tabular}

Tablo 3 incelendiğinde ölçeğin öğrenci merkezli tasarım faktöründe yer alan maddelerin ortalaması, 4.24 ile kesinlikle katılıyorum düzeyde çıkmıştır. Katılımcıların verdiği cevaplar içinde en düşük ortalama 3.93 ile "Derste çoğunlukla problem çözme yöntemi kullanılmalıdır" maddesi iken, en yüksek ortalama ise 4.56 ile "Derste, öğrencinin ilgi, ihtiyaç ve beklentileri dikkate alınmalıdır" maddesidir.

\section{Konu Merkezli Tasarım Faktörüne ilişkin Bulgular}

Araştırmanın ikinci alt problemi "Öğretmenlerin konu merkezli tasarım faktörüne ilişkin görüşleri nelerdir?" şeklinde belirlenmiştir. Öğretmenlerin konu merkezli tasarım yaklaşımına ilişkin görüşlerinin aritmetik ortalama ve standart sapma değerleri Tablo 4 'te sunulmuştur. 
Tablo 4. Konu Merkezli Tasarım Faktörüne Ilişskin Aritmetik Ortalama ve Standart Sapma Sonuçlart

\begin{tabular}{|c|c|c|c|}
\hline Maddeler & $\mathrm{N}$ & $x$ & $\mathrm{~S}$ \\
\hline $\begin{array}{l}\text { M14.Derste, konuların öğrenilmesi önemli } \\
\text { bir yer tutmalıdır }\end{array}$ & 292 & 3.81 & 1.05 \\
\hline $\begin{array}{l}\text { M15.Programlar, değişmeyen evrensel } \\
\text { bilgiye göre düzenlenmelidir }\end{array}$ & 292 & 3.49 & 1.26 \\
\hline $\begin{array}{l}\text { M17. Derste önemli olan şey bilginin } \\
\text { aktarılmasıdır. }\end{array}$ & 292 & 3.06 & 1.29 \\
\hline $\begin{array}{l}\text { M18. Derste, grup çalışmalarından daha } \\
\text { ziyade bireysel çalışmalara yer verilmelidir. }\end{array}$ & 292 & 2.86 & 1.16 \\
\hline $\begin{array}{l}\text { M20. Derslerde, her konu için ayrı ayrı } \\
\text { ögrenme yolu düzenlemek yerine, tüm } \\
\text { konular için ortak bir öğrenme yolu ön plana } \\
\text { çıkarılmalıdır. }\end{array}$ & 292 & 2.80 & 1.31 \\
\hline $\begin{array}{l}\text { M21.Derse öğrencilerin ilgi ve isteklerini } \\
\text { yansıtmanın gereği yoktur. }\end{array}$ & 292 & 2.09 & 1.30 \\
\hline $\begin{array}{l}\text { M23.Öğrenciler bilgileri alıc1 ve } \\
\text { ezberleyicidirler }\end{array}$ & 292 & 2.48 & 1.37 \\
\hline $\begin{array}{l}\text { M25.Öğrencilerin, bilginin farklı dallarında } \\
\text { uzmanlaşması önemlidir }\end{array}$ & 292 & 3.93 & 1.12 \\
\hline $\begin{array}{l}\text { M28.Derste, öğrencilerden daha ziyade } \\
\text { ögretmen aktif olmalıdır. }\end{array}$ & 292 & 2.46 & 1,27 \\
\hline $\begin{array}{l}\text { M30. Programlarda, içerik öğesi daha fazla } \\
\text { ön plana çıarılmalıdır }\end{array}$ & 292 & 2.95 & 1,23 \\
\hline Toplam & 292 & 2.99 & .681 \\
\hline
\end{tabular}

Tablo 4 incelendiğinde ölçeğin konu merkezli tasarım faktöründe yer alan maddelerin ortalaması 2,99 ile kararsızım düzeyinde çıkmıştır. Katılımcıların verdiği cevaplar içinde en düşük ortalama 2.09 ile "Derse öğrencilerin ilgi ve isteklerini yansıtmanın gereği yoktur" maddesi iken en yüksek ortalamanın ise 3.81 ile "Derste konuların öğrenilmesi önemli bir yer tutmalıdır" maddesi olduğu görülmektedir.

\section{Sorun Merkezli Tasarım Faktörüne İlişkin Bulgular}

Araştırmanın üçüncü alt problemi "Öğretmenlerin sorun merkezli tasarım faktörüne ilişkin görüşleri nelerdir?” şeklinde belirlenmiştir. Öğretmenlerin sorun merkezli tasarım yaklaşımına ilişkin görüşlerinin aritmetik ortalama ve standart sapma değerleri Tablo 5 'te sunulmuştur.

Tablo 5. Sorun Merkezli Tasarım Faktörüne Illişkin Aritmetik Ortalama ve Standart Sapma Sonuçları

\begin{tabular}{lccc}
\hline & $\mathrm{N}$ & $x$ & $S$ \\
\hline $\begin{array}{l}\text { Maddeler } \\
\text { olmalıdıl, demokratik süreçlerin yaşatıldığı bir yer }\end{array}$ & 292 & 4.42 & .776 \\
$\begin{array}{l}\text { M5. Okul, günün önemli bir bölümünü çok yönlü } \\
\text { çalışmayı ve disiplinler arası bağlantılar kurmayı } \\
\text { gerçekleştirecek şekilde problematik çalışmalara } \\
\text { ayırmalıdır. }\end{array}$ & & & \\
$\begin{array}{l}\text { M10.Okullarda, tüm öğrencilerin öğrenmesi gereken } \\
\text { ortak öğrenme tecrübeleri temele alınmalıdır. }\end{array}$ & 292 & 4.24 & .808 \\
\end{tabular}


M13.Derslerde, toplum gereksinim ve sorunları ele alınmalidır.

M16. Programlarda, yaşama ilişkin gerçek sorunlar yer almalidir.

M19. Derslerde öğrenciler sorun çözme sürecini kullanmaya özendirilmelidir

$\begin{array}{lll}292 & 3.89 & 1.07\end{array}$

M22. Okulda, öğrencilerin işbirliği yaparak toplumsal sorunlara çözümler bulması özendirilmelidir.

M26. Okullarda, sosyal değerlerin öğrencilere kazandırılması çok önemlidir.

M27. Toplumsal değişmede okullar ve eğitim kritik bir role sahip bulunmaktadır.

M29. Okulda öğrenciler, gerçek yaşam problemlerine yönelik genelleme becerisi

kazandırılmalıdır. Toplam

$292 \quad 4.08 \quad .975$

$292 \quad 4.40 \quad .808$

$292 \quad 4.25 \quad .880$

$292 \quad 3.70 \quad 1.16$

$292 \quad 4.14 \quad 4.17$

Tablo 5 incelendiğinde ölçeğin sorun merkezli tasarım faktöründe yer alan maddelerin ortalaması 4.14 ile katılıyorum düzeyinde çıkmıştır. Katılımcıların verdiği cevaplar içinde en düşük ortalama 3.70 ile "Okulda öğrenciler, gerçek yaşam problemlerine yönelik genelleme becerisi kazandırılmalıdır" maddesi iken en yüksek ortalamanın ise 4.42 ile "Okul, demokratik süreçlerin yaşatıldığı bir yer olmalıdır" maddesi olduğu görülmektedir.

\section{Cinsiyet Değişkenine ilişkin Bulgular}

Araştırmanın dördüncü alt probleminin a seçeneği "Öğretmenlerin eğitim programı tasarım yaklaşımı tercihleri cinsiyete göre farklılaşmakta mıdır?" şeklinde belirlenmiştir. Öğrenci merkezli tasarım yaklaşımına ilişkin öğretmen görüşleri $t$ testi sonuçları Tablo 6' da sunulmuştur.

Tablo 6. Öğretmenlerin Cinsiyet Değişkenine Göre Eğitim Programı Tasarım Yaklaşımı Tercihlerini Belirleme Yönelik Yapılan t-Testi Sonuçları

\begin{tabular}{llcccccc}
\hline Boyutlar & Cinsiyet & $\mathrm{N}$ & $\bar{x}$ & $\mathrm{~S}$ & $\mathrm{sd}$ & $\mathrm{t}$ & $\mathrm{p}$ \\
\hline Öğrenci merkezli & Erkek & 173 & 4.260 & .4658 & 290 & .708 & .480 \\
& Kadın & 119 & 4.225 & .3454 & & & \\
Konu merkezli & Erkek & 173 & 3.048 & .6600 & 290 & 1.533 & .126 \\
& Kadın & 119 & 2.924 & .7089 & & & \\
Sorun merkezli & Erkek & 173 & 4.176 & .3897 & 290 & 1.334 & .183 \\
& Kadın & 119 & 4.110 & .4535 & & & \\
Toplam & Erkek & 173 & 3.828 & .3297 & 290 & 1.909 & .057 \\
& Kadın & 119 & 3.753 & .3322 & & & \\
\hline
\end{tabular}

Cinsiyet değişkenine göre erkek ve kadın öğretmenlerin eğitim programı tasarım yaklaşımı tercihlerini karşılaştırmak için bağımsız gruplar t-testi uygulanmıştır. Analiz sonucuna göre eğitim programı tasarım yaklaşımı ölçeğindeki öğrenci merkezli $(\mathrm{p}=.480)$; konu merkezli $(\mathrm{p}=.126)$; sorun merkezli $(\mathrm{p}=.183)$ alt boyutları ile eğitim programı tasarım yaklaşımı toplam tercihlerine göre $(\mathrm{p}=.057)$ cinsiyet değişkeni açısından anlamlı bir farklılık bulunmamıştır. Diğer bir ifade ile öğretmenlerin eğitim programı tasarım yaklaşımı tercihleri, cinsiyet değişkenine göre gerek ölçeğin alt boyutları, gerekse bütünü açısından anlamlı biçimde farklılaşmamaktadır. 


\section{Ĕ̌itim Durumu Değişkenine İlişkin Bulgular}

Araştırmanın dördüncü alt probleminin b seçeneği "Öğretmenlerin eğitim programı tasarım yaklaşımı tercihleri eğitim durumu değişkenine göre farklılaşmakta mıdır? şeklinde belirlenmiştir. Öğretmenlerinin eğitim programı tasarım yaklaşımı tercihlerinin eğitim durumu değişkenine göre farklılaşma olup olmadığına belirlemek için yapılan t testi sonuçları Tablo 7'de sunulmuştur.

Tablo 7. Öğretmenlerin Eğitim Programı Tasarım Yaklaşımı Tercihlerinin Eğitim Durumu Değişkenine Göre t-Testi Sonuçlart

\begin{tabular}{llllcccc}
\hline Boyutlar & Eğitim Durumu & $\mathrm{N}$ & $\bar{x}$ & $\mathrm{~S}$ & $\mathrm{sd}$ & $\mathrm{t}$ & $\mathrm{p}$ \\
\hline Öğrenci Merkezli & Lisans & 255 & 4.248 & .4322 & 290 & .213 & .831 \\
& Lisans Üstü & 37 & 4.232 & .3350 & & & \\
Konu Merkezli & Lisans & 255 & 3.007 & .6909 & 290 & .650 & .516 \\
& Lisans Üstü & 37 & 2.929 & .6204 & & & \\
\multirow{2}{*}{ Sorun Merkezli } & Lisans & 255 & 4.150 & .4211 & 290 & .095 & .925 \\
& Lisans Üstü & 37 & 4.143 & .3961 & & & \\
Toplam & Lisans & 255 & 3.802 & .3400 & 290 & .575 & .566 \\
& Lisans Üstü & 37 & 3.768 & .2749 & & & \\
\hline
\end{tabular}

Eğitim değişkenine göre lisans mezunu ve lisansüstü mezunu öğretmenlerin eğitim programı tasarım yaklaşımı tercihlerini karşılaştırmak için bağımsız gruplar t-testi kullanılmıştır. Analiz sonucuna göre ölçeğin öğrenci merkezli $(\mathrm{p}=.831)$, konu merkezli $(\mathrm{p}=.516)$, sorun merkezli $(\mathrm{p}=.925)$ alt boyutları ile eğitim programı tasarım yaklaşımı tercihleri $(\mathrm{p}=.566)$ eğitim durumu değişkeni açısından anlamlı bir farklılık göstermemektedir. Diğer bir ifadeyle öğretmenlerin eğitim programı tasarım yaklaşımı tercihleri, eğitim durumu değişkenine göre gerek ölçeğin alt boyutları, gerekse bütünü açısından anlamlı biçimde farklılaşmamaktadır.

\section{Kudem Değişkenine ilişkin Bulgular}

Araştırmanın dördüncü alt problemi c seçeneği "Öğretmenlerin eğitim programı tasarım yaklaşımı tercihleri eğitim durumu değişkenine göre farklılaşmakta mıdır?" ş̧eklinde belirlenmiştir. Öğretmenlerin eğitim programı tasarım yaklaşımı tercihlerinin kıdem değişkenine gore farklılaşma olup olmadığına belirlemek için yapılan Anavo sonuçları Tablo 8 'de sunulmuştur.

Tablo 8. Öğretmenlerin Ĕgitim Programı Tasarım Yaklaşımı Tercihlerinin Mesleki Kıdem Değişkenine Göre Anavo Sonuçları

\begin{tabular}{|c|c|c|c|c|c|c|c|}
\hline Boyutlar & Kidem & $\mathrm{N}$ & $\bar{x}$ & $\mathrm{~S}$ & $\mathrm{~F}$ & Sig. & Anlamlı Fark \\
\hline & $1.0-5 \mathrm{y} 1 \mathrm{l}$ & 94 & 4.15 & .432 & & & \\
\hline & 2. 6-10 y1l & 71 & 4.33 & .376 & & & \\
\hline Öğrenci & $3.11-15$ y1l & 49 & 4.32 & .433 & 2.44 & .057 & - \\
\hline \multirow[t]{3}{*}{ Merkezli } & $4.16-20 \mathrm{y} 11$ & 46 & 4.20 & .468 & & & \\
\hline & 5. 20 Yil ve Üzeri & 32 & 4.25 & .343 & & & \\
\hline & Toplam & 292 & 4.24 & .420 & & & \\
\hline Konu & $1.0-5$ y1l & 94 & 2.91 & .596 & & & \\
\hline \multirow[t]{5}{*}{ Merkezli } & 2. $6-10$ y1l & 71 & 2.88 & .664 & 4.76 & .001 & $5-1,4-1$ \\
\hline & $3.11-15$ y1l & 49 & 2.98 & .844 & & & $5-2,4-2$ \\
\hline & $4.16-20 \mathrm{y} 11$ & 46 & 3.23 & .671 & & & $5-3,4-3$ \\
\hline & 5.20 y1l ve Üzeri & 32 & 3.17 & .521 & & & $5-4$ \\
\hline & Toplam & 292 & 3.03 & .681 & & & \\
\hline Sorun & 1. $0-5 \mathrm{y} 11$ & 94 & 4.07 & .415 & & & \\
\hline
\end{tabular}




\begin{tabular}{|c|c|c|c|c|c|c|}
\hline Merkezli & 2. 6-10 y1l & 71 & 4.24 & 420 & 1.91 & . 108 \\
\hline & $3.11-15$ y1l & 49 & 4.13 & 417 & & \\
\hline & 4.16-20 y1l & 46 & 4.13 & 377 & & \\
\hline & 5. 20 yıl ve Üzeri & 32 & 4.20 & 446 & & \\
\hline & Toplam & 292 & 4.14 & 417 & & \\
\hline Toplam & $1.0-5 y 11$ & 94 & 3.71 & .301 & & \\
\hline & 2.6-10y1l & 71 & 3.82 & .326 & 3.10 & .061 \\
\hline & $3.11-15 y_{1} 1$ & 49 & 3.78 & .381 & & \\
\hline & $4.16-20 \mathrm{y} 11$ & 46 & 3.84 & .326 & & \\
\hline & 5. 20 Yll ve üzeri & 32 & 3.98 & .316 & & \\
\hline & Toplam & 292 & 3.82 & .335 & & \\
\hline
\end{tabular}

Mesleki kıdem değişkenine göre ilkokul, ortaokul ve lisede görev yapan öğretmenlerin eğitim programı tasarım yaklaşımı tercihlerini karşılaştırmak için tek yönlü anova testi kullanılmıştır. Anova testi sonuçları incelendiğinde öğretmenlerin eğitim programı tasarım yaklaşım tercihlerinin konu merkezli tasarım boyutunda farklılaştığı görülmektedir $(p<0,05)$. Farklılığın kaynağı incelendiğinde 0-5 y1l ile 20 yıl ve üzeri, 6- 10 y1l ile 20 y1l ve üzeri, 11 - 15 yıl ile 20 yıl ve üzeri 16-20 yıl ile 20 yıl ve üzeri kıdeme sahip öğretmenler arasında 20 yıl ve üzeri kıdeme sahip öğretmenler lehine şeklindedir. Diğer bir ifade ile 20 yıl üzeri kıdeme sahip öğretmenler konu merkezli tasarımı tercih ettikleri söylenebilir.

\section{Okul Kademesi Değiş̧kenine İliş̧kin Bulgular}

Araştırmanın dördüncü alt problemi d seçeneği "Öğretmenlerinin eğitim programı tasarım yaklaşımı tercihleri okul kademesi değişkenine göre farklılaşmakta mıdır?" şeklinde belirlenmiştir. Öğretmenlerin eğitim programı tasarım yaklaşımı tercihlerinin okul kademesi değişkenine göre farklılaşma olup olmadığına belirlemek için yapılan Tek Yönlü Anova sonuçları Tablo 9'da sunulmuştur.

Tablo 9. Öğretmenlerin Eğitim Programı Tasarım Yaklaşımı Tercihlerinin Okul Kademesi Değişkenine Göre Anavo Sonuçlart

\begin{tabular}{|c|c|c|c|c|c|c|c|}
\hline Boyutlar & Kademe & $\mathrm{N}$ & & $\bar{x}$ & $\mathrm{~S}$ & $\mathrm{~F}$ & $\mathrm{P}$ \\
\hline \multirow[t]{4}{*}{ Öğrenci merkezli } & İlkokul & & 77 & 4.276 & .4058 & & \\
\hline & Ortaokul & & 125 & 4.251 & .4298 & .483 & .617 \\
\hline & Lise & & 90 & 4.213 & .4227 & & \\
\hline & Total & & 292 & 4.246 & 4207 & & \\
\hline \multirow[t]{4}{*}{ Konu Merkezli } & İlkokul & & 77 & 2.967 & .7576 & & \\
\hline & Ortaokul & & 125 & 3.048 & .5831 & & \\
\hline & Lise & & 90 & 2.954 & .7417 & .595 & .552 \\
\hline & Total & & 292 & 2.997 & .6819 & & \\
\hline \multirow[t]{4}{*}{ Sorun merkezli } & İlkokul & 77 & & 174 & .4769 & & \\
\hline & Ortaokul & 125 & & 138 & .3864 & & \\
\hline & Lise & 90 & & 143 & .4083 & 186 & .831 \\
\hline & Total & 292 & & 149 & .41745 & & \\
\hline \multirow[t]{4}{*}{ Toplam } & İlkokul & 77 & & 806 & .39617 & & \\
\hline & Ortaokul & 125 & & 812 & .28419 & .452 & .637 \\
\hline & Lise & 90 & & 770 & .33656 & & \\
\hline & Total & 292 & & 797 & .33225 & & \\
\hline
\end{tabular}

Okul Kademesi değişkenine göre ilkokul, ortaokul ve lisede görev yapan öğretmenlerin eğitim programı tasarım yaklaşımı tercihlerini karşılaştırmak için Tek Yönlü Anova Testi kullanılmıştır. Yapılan testin sonuçları incelendiğinde öğretmenlerin eğitim programı tasarım 
yaklaşımı tercihleri hem ölçeğin alt boyutları hem de bütünü için anlamlı biçimde farklılaşmamaktadır ( $\mathrm{p}>0.05)$.

\section{Sonuç, Tartışma ve Öneriler}

Araştırma sonuçları incelendiğinde eğitim programı tasarım yaklaşımı tercihleri ölçeğinin öğrenci merkezli tasarım faktöründe yer alan maddelerin ortalaması kesinlikle katıllyorum düzeyinde çıkmıştır. Bu sonuç Demirel (2011) tarafından ifade edilen özellikle 20.yy ile birlikte tüm program tasarımcılarının öğreneni ön planda tuttuğuna yönelik görüşleriyle örtüşmektedir. $\mathrm{Bu}$ sonucun ortaya çıkmasında öğrenci merkezli öğretim tasarımında ön plana çıkan ve modern dünyada birçok ülkede yaygın olarak kullanılan yapılandırmacıllı̆ın (Eğitim reformu girişimi, 2005;Yurdakul, 2016) 2005-2006 eğitim öğretim yılından itibaren Milli Eğitim Bakanlı̆̆ tarafından kullanılması ve müfredatı yapılandırmacılığa göre tasarımlamasının (Kesten ve Özdemir, 2010; Bıkmaz, 2006; Karadağ, Deniz, Korkmaz ve Deniz, 2008; Yapıc1 ve Leblebiciler, 2007) etkili olduğu söylenebilir. Bu konuda yapılan çalışmalar incelendiğinde öğretmen adaylarının ve öğretmenlerin yapılandırmacı eğitim anlayışını olumlu buldukları söylenebilir. Kasapoğlu ve Duban (2012) tarafından yapılan çalışmada sınıf öğretmeni adaylarının yapılandırmacılığa yönelik tutumlarının pozitif yönde olduğu ve derslerini öğrenci merkezli yaklaşım olan yapılandırmacılığa göre yapmakta istekli oldukları sonucuna ulaşılmıştır. Karadağ ve diğerleri (2008) tarafından yapılan çalışmada sınıf öğretmenlerinin eğitim durumu, sınıf içi iletişim ve sınıf yönetiminde sıklıkla yapılandırmacılık yaklaşımını kullandığı sonucuna varılmıştır. Bulut (2008) tarafından yapılan çalışmada ise öğretmenlerin yapılandırmacılık çerçevesinde oluşturulan yeni programları öğrenci merkezli olarak yürüttükleri sonucuna ulaşılmıştır. Buna karşın öğrenci merkezli programların öğretmenler tarafından tam olarak anlaşılamaması ve hizmet eğitiminin yetersiz kalmasına yönelik birçok araştırma da mevcuttur (Bıkmaz, 2006; Yapıc1 ve Leblebiciler, 2007; Bal, 2008; Kesten ve Özdemir, 2010).

Eğitim programı tasarım yaklaşımı tercihleri ölçeğinin konu merkezli tasarım faktöründe yer alan maddelerin ortalaması" kararsızım" düzeyinde çıkmıştır. Diğer bir ifade ile öğretmenler konu merkezli yaklaşımı kullanmak ile öğrenci merkezli yaklaşım kullanma arasında ikilemde kaldığ1 söylenebilir. Bunun nedeni olarak ise Erdoğan (2007) tarafından yapılan çalışmada yapılandırmacılığın öğretmenler tarafından uygulanmak istendiği; ancak materyal eksikliği, alt yap1 yetersizliği, üniversitedeki eğitim programlarının öğrenci merkezli olarak düzenlenememesi olarak değerlendirilebilir. Özdemir (2010) tarafindan yapılan çalışmada öğrenci merkezli yaklaşımda kullanılan alternatif ölçme değerlendirme tekniklerinin öğretmenler tarafından bilinmediği ve hizmet içi eğitime ihtiyaç duyulduğu ifade edilmektedir. Yapıcı ve Demirdelen'in (2007) yaptığı çalışmada yapılandırmacılığa uygun öğrenci merkezli yaklaşımının uygulanmasına yönelik olarak öğretmenler uygun ölçme değerlendirme tekniklerini hazırlama konusunda eksikliklerinin olduğunu belirtmiştir. Duru ve Korkmaz'a (2010) göre öğretmenlere, öğrenci merkezli programın yeterince anlatılamaması, sınıfların kalabalık olması, araç-gereç eksikliği ise bir diğer önemli sorun olarak dikkat çekmektedir. Orbeyi ve Güven (2008)'e göre öğrenci merkezli yaklaşım olan yapılandırmacılığa yönelik öğretmen adaylarının hizmet içi eğitime ihtiyaç duydukları ve bu eğitimin yeterliliğe sahip kişiler tarafından verilmesi gerekliliği ifade edilmektedir. Yine Kesten ve Özdemir'e (2010) göre konu-öğretmen merkezli anlayıştan öğrenci merkezli anlayışa geçişte gerekli hazırlıkların yapılmaması ve donanım eksikliğinden dolayı öğrenci merkezli yaklaşım bir çok sorunu beraberinde getirmektedir. Sonuç olarak yapılan çalışmalarda öğrenci merkezli yaklaşımla ilgili birçok sorun ifade edilmekte ve bu sorunlar öğretmenleri öğrenci merkezli yaklaşımla konu merkezli yaklaşımı uygulama konusunda ikileme düşürmektedir. $\mathrm{Bu}$ araştırmadaki öğretmenlerin konu merkezli tasarım faktörüne yönelik görüşlerinin ortalamasının "kararsızım" düzeyindeki sonuç ile yukarıda belirtilen diğer araştırma sonuçları ve literatür arasında paralellik olduğu söylenebilir.

Eğitim programı tasarım yaklaşımı tercihleri ölçeğinin, sorun merkezli tasarım faktöründe yer alan maddelerin ortalaması "katılıyorum" düzeyinde çıkmıştır. Sorun merkezli tasarımın öğrenci merkezli tasarımla ilişkili olduğunu ifade eden Demirel (2011) bu tasarımın daha çok konu alanı ve öğrenci merkezli yaklaşımdaki eksiklikleri gidermek amacıyla ortaya konulduğunu; sorun merkezli tasarımda ise daha çok sorun çözmenin ön planda olduğunu ifade etmektedir. 
Öğrenen merkezli yaklaşımda öğretmenlerin "kesinlikle katılıyorum" düzeyinde cevap vermesinin ardından sorun merkezli yaklaşıma "katılıyorum" derecesinde cevap vermesi bu bağlamda öğretmen görüşleri arasında bir tutarlılığın olduğu şeklinde de yorumlanabilir.

Öğretmenlerin eğitim programı tasarım yaklaşımı tercihleri, cinsiyet değişkenine göre hem ölçeğin alt boyutları, hem de bütünü açısından anlamlı biçimde farklılaşmamaktadır. $\mathrm{Bu}$ sonuç 2005 yılında yenilenen ilköğretim I. kademe programlarında öngörülen öğrenci merkezli uygulamalara ilişkin öğretmen görüşlerini belirlemeye yönelik Bulut'un (2008) araştırma sonuçlarıyla paralellik göstermektedir. Yine Aygören ve Saraçoğlu (2015) tarafindan yapılan çalışmada öğrenci merkezli yaklaşım olan yapılandırmacı öğrenme ortamı ve etkinlik oluşturmada cinsiyet değişkenine ilişsin anlamlı bir farklılık bulunmadığına yönelik sonucu bu araştırmanın sonuçlarını desteklemektedir.

Öğretmenlerin eğitim programı tasarım yaklaşımı tercihleri eğitim durumu değişkenine göre, gerek ölçeğin alt boyutları gerekse bütünü açısından anlamlı biçimde farklılaşmamaktadır. Araştırmada yüksek lisans mezunu öğretmenlerin lisans mezunu öğretmenlere göre daha fazla öğrenci merkezli tasarımı tercih etmeleri beklenmekle birlikte; böyle bir sonuca ulaşılamamıştır. $\mathrm{Bu}$ durumun nedeninin daha net açıklanabilmesi için öğretmenlerin lisans üstü eğitimlerini kendi alanlarında mı yoksa eğitim bilimleri alanında mı yaptıklarının bilinmesi gerekir. Eğitim bilimleri alanında yüksek lisans yapan öğretmenlerin eğitim bilimleri alanındaki gelişmeleri takip etmesi ve bu doğrultuda yapılandırmacı eğitim anlayışına uygun öğrenci merkezli tasarımı tercih etmesi beklenmektedir.

Öğretmenlerin eğitim programı tasarım yaklaşımı tercihleri kıdem değişkenine göre konu merkezli tasarım boyutunda farklılaştığı görülmektedir. Farklılığın kaynağ incelendiğinde 1-5 yıl ile 20 y1l ve üzeri, 6- 10 y1l ile 20 y1l ve üzeri, 11 - 15 y1l ile 20 y1l ve üzeri , 16-20 y1l ile 20 y1l ve üzeri kıdeme sahip öğretmenler arasında 20 yıl ve üzeri kıdeme sahip öğretmenler lehinedir. Öğretmenlerin kıdemleri artıkça daha fazla konu merkezli tasarımı tercih ettikleri görülmektedir. Bu sonuca ulaşılmasında 2005 yılından önce daha çok konu merkezli eğitim anlayışının Türk Eğitim Sisteminde hâkim olmas1 etkili olmuş olabilir. Çünkü 20 yılın üzerinde k1deme sahip öğretmenler hem yüksek öğretimde daha çok konu merkezli tasarıma uygun eğitim almış olmaları hem de 2005 yılından önce uzun bir süre konu merkezli tasarıma uygun öğretim yapmasından kaynaklandığı düşünülmektedir.

Okul kademesi değişkenine göre ilkokul, ortaokul ve lisede çalışan öğretmenlerin eğitim programı tasarım yaklaşımı tercihleri hem ölçeğin alt boyutları hem de bütünü için anlamlı biçimde farklılaşmadığı sonucuna ulaşılmıştır. Değişik okul kademesinde çalışan öğretmenlerin program tasarımları tercihleri konusunda benzer düşüncelere sahip olduğu söylenebilir. Elde edilen bulgular çerçevesinde şu önerilerde bulunulabilir;

1. 20 yıl ve üzeri kıdeme sahip öğretmenlerin daha fazla konu merkezli program tasarımı tercih etmeleri, öğrenci merkezli modelin benimsendiği yapılandırmacılık eğitim anlayışının öncelendiği eğitim sisteminde bir eksiklik olarak düşünülebilir. Söz konusu bu eksikliğin giderilmesi amacıyla hizmet içi eğitim kursları düzenlenebilir. $\mathrm{Bu}$ kurslarda ögrenci ve sorun merkezli program tasarımını tercih etmenin etkili bir öğrenme sürecinin gerçekleşmesindeki rolü üzerine durulabilir. Ayrıca söz konusu öğretmenlere yönelik yapılacak nitel araştırmalarla neden konu merkezli tasarımı tercih ettikleri araştırılabilir.

2. Öğretmen adaylarının yetiştirilmesi sürecinde öğrenci merkezli program tasarımına yönelik etkinliklerin nasıl uygulanacağına yönelik çalışmalar yapılabilir.

3. Üniversitelerdeki akademisyenlerin hangi program tasarımını tercih ettiklerine yönelik araştırmalar yapılabilir.

4. Öğretmen/ öğretmen adaylarının program tasarımları konusundaki bilgi düzeyleri araştırılabilir.

5. Öğretmenlerin program tasarım tercihlerini belirleyen faktörler üzerinde araştırma yapilabilir.

\section{Kaynaklar}


Akkoyunlu, B., Altun, A. ve Soylu, M.Y. (2008). Öğretim tasarımı. Ankara: Maya Akademi.

Alc1, B. (2012). Eğitim programı tasarımı ve modeller. Hasan Şeker (Ed.), Eğitimde program geliştirme içinde (s.71-88). Ankara: Anı Yayıncılık.

Aygören, F. ve Saracaoğlu, A. S. (2015). Sınıf öğretmenlerinin yapılandırmacı öğrenme ortamlarına ilişkin görüşleri. Mehmet Akif Ersoy Üniversitesi Eğitim Fakültesi Dergisi, 1(34), 194-223.

Aydıner, N. (2015). Eğitim Programları ve Öğretim. Asuman Seda Saracaloğlu ve Adnan Küçükoğlu (Ed.) Öğretim Illke ve Yöntemleri içinde (s.21-54). Ankara: Pegem Akademi

Aykaç, N.(2014). Öğretim ilke ve yöntemleri. Ankara: Pegem Akademi.

Bal, A.P. (2008). Yeni ilköğretim matematik öğretim programının öğretmen görüşleri açısından değerlendirilmesi. Çukurova Üniversitesi Sosyal Bilimler Enstitüsü Dergisi, 17(1),5368.

Balc1, A. (2001). Sosyal bilimlerde araştırma: Yöntem, teknik ve ilkeler. Ankara: PegemA Yayıncilik.

Baş, G. (2013). Öğretmenlerin eğitim programı tasarım yaklaşımı tercih ölçeği: Geçerlik ve güvenirlik çalışması. Kuram ve Uygulamada Eğitim Bilimleri, Educational Sciences: Theory \& Practice, 13(2), 965-992

B1kmaz, F.H. (2006). New elementary curricula and teachers. Ankara University Journal of Faculty of Educational Sciences, 39(1), 97-116.

Çeliköz, N. (2004). Yeni program geliştirme anlayışına dayalı olarak geliştirilen bir program tasarımının öğrenci başarısına etkisi. Gazi Üniversitesi Gazi Eğitim Fakültesi Dergisi, 24(1), 99-113.

Demirel, Ö. (2011). Eğitimde program geliştirme. Ankara: Pegem Yayınları.

Duru, A. ve Korkmaz, H. (2010). Öğretmenlerin yeni matematik programı hakkındaki görüşleri ve program değişim sürecinde karşılaşılan zorluklar. Hacettepe Üniversitesi Eğitim Fakültesi Dergisi, 38(38), 67-81

Eğitim Reformu Girişimi, (2005). Yeni Öğretim Programlarını İnceleme ve Değerlendirme http://www.egitimreformugirisimi. org Adresinden 24.09.2016 tarihinde erişilmiştir.

Erden, M. (1993). Ĕgitimde program değerlendirme. Ankara: Pegem Yayınları

Erdoğan, M. (2007). Yeni geliştirilen dördüncü ve beşinci sınıf fen ve teknoloji dersi öğretim programının analizi: Nitel bir çalışma. Türk Eğitim Bilimleri Dergisi, 5(2), 221-259.

Ertürk, S. (1982). Eğitimde program geliştirme. Ankara: Yelkentepe Yayınları.

Kahyaoğlu, M. ve Yangın, S (2007). İlköğretim öğretmen adaylarının mesleki öz-yeterliklerine ilişkin görüşleri. Kastomonu Eğitim Dergisi, 15(1), 73-84.

Karadağ, E., Deniz, S., Korkmaz, T. ve Deniz, G. (2008). Yapılandırmacı öğrenme yaklaşımı: sınıf öğretmenleri görüşleri kapsamında bir araştırma, Uludă̆ Üniversitesi Eğitim Fakültesi Dergisi, 21(2), 383-402.

Karasar N. (2000). Bilimsel araştırma yöntemi. Ankara: Nobel Yayınları.

Kasapoğlu, K. ve Duban, N. (2012). Sınıf öğretmeni adaylarının yapılandırmacı yaklaşımı uygulamaya yönelik öz yeterlik inançlarını yordayan bir faktör olarak yapılandırmacı yaklaşıma yönelik tutumları (Afyonkarahisar İli Örneği). Mersin Üniversitesi Eğitim Fakültesi Dergisi, 8(2), 85-96.

Kesten, A. ve Özdemir, N. (2010). Sosyal bilgiler öğretim programinin ölçmedeğerlendirme boyutunun öğretmen görüşlerine göre değerlendirilmesi: Samsun ili örneği. Firat Üniversitesi Sosyal Bilimler Dergisi, 20(2), 223-236.

Küçüktepe, C. (2011). Eğitimde program geliştirme süreci. (Ed.Uzunboylu, H. ve Öner, G). Öğretim ilke ve yöntemleri içinde (s.25-44). İstanbul: Lisans Yayıncılık.

Küçüktepe, C. (2012). Program geliştirme süreci, Program geliştirmede çalışma grupları ve çalışma planı hazırlama-İhtiyaç belirleme yaklaşım ve teknikleri (Ed.Şeker, H). Eğitimde Program Geliştirme Kavramlar ve Yaklaşımlar içinde (s.89-125). Ankara: Anı Yayincilik.

Marsh, C.J. (2004). Key concepts for understanding curriculum. (Third Edition). London: Routledge. 
Orbeyi, S. ve Güven, B. (2008). Yeni ilköğretim matematik dersi öğretim programı'nın değerlendirme öğesine ilişkin öğretmen görüşleri. Eğitimde Kuram ve Uygulama, 4(1), 133-147.

Ornstein, A.C ve Hunkins, F.P. (2014). Eğitim programı. (Çev. Asım Arı). Konya: Eğitim Yayınevi.

Özdemir, S.M. (2010). İlköğretim öğretmenlerinin alternatif ölçme ve değerlendirme araçlarına ilişkin yeterlikleri ve hizmet içi eğitim ihtiyaçları. Türk Eğitim Bilimleri Dergisi, 8(4), 787-816.

Sönmez, V. (2012). Program geliştirmede öğretmen elkitabı. (17.Baskı). Ankara: Anı Yayıncilik

Varış, F. (1996). Egitimde program gelistirme: teori ve teknikler. Ankara: Alkim Yayıncılık

Yapıc1, M. ve Demirdelen, C. (2007). İlköğretim 4. sınıf sosyal bilgiler öğretim programına ilişkin öğretmen görüşleri. Illköğretim Online, 6(2), 204-212.

Yapıc1, M. ve Leblebiciler, N.H. (2007). Öğretmenlerin yeni ilköğretim programına ilişkin görüşleri. İlköğretim Online, 6(3), 480-490

Yurdakul, B. (2016). Yapılandırmacıl1k. Pegem Atıf Indeksi, (5), 39-65.

Yüksel, İ. ve Sağlam, M. (2012). Eğitimde program değerlendirme. Ankara: Pegem Akademi.

\section{Extended Abstract}

Curriculum design orientation is a process by which the components of the program are uncovered, and it aims to deal with the organization of education (Demirel, 2011). Ornstein and Hunkins (2014) state that curriculum design orientation refers to the process related to the four components of the program including objectives, subject matter, learning activities and evaluation. Alc1 (2012) describes curriculum design orientation as the process through which the components of a program are determined. In particular, it is essential to design the program while planning the education program. Designing the education program has a significant role in identifying the main framework of education program. Emphasizing the importance of the determination of curriculum design orientations, Baş (2013) indicates that curriculum design orientation preferences are of paramount significance to reveal teachers' expectations, preferences, practices as well as their attitudes in classroom. The present study aims to investigate teachers' views on their curriculum design orientations preferences in terms of some variables. Accordingly, answers for the following questions have been sought:

\section{Research Questions}

1. What are the teachers' views regarding student-centred curriculum design orientation factor within curriculum design orientation?

2. What are the teachers' views regarding subject-centred curriculum design orientation factor within curriculum design orientation?

3. What are the teachers' views regarding problem-centred curriculum design orientation factor within curriculum design orientation?

4. Do teachers' views regarding curriculum design orientation preferences differ depending upon;
a. Gender,
b. Education status,
c. Occupational seniority,
d. School type variables?

\section{Method}

\section{Research Design}

Being a descriptive study, this research has a survey model design. Karasar defines screening (survey) models as an approach that aims to describe a situation existing in the past or current. The main objective of this study is to determine whether teachers' views regarding their curriculum design orientation preferences differ across gender, educational level, occupational seniority and school type. 


\section{Population and Sample}

The population of the study consisted of teachers working at schools located within the province of Hatay in Turkey. The sample constitutes 292 teachers who were selected by the simple random sampling method. The research used "simple random sampling method". This method implies that each unit in the universe has an equal chance of being selected for the sample (Balc1, 2001; Karasar, 2012).

\section{Data Collection Tool}

This research has employed the "Curriculum Design Orientations Preference Scale" developed by Baş (2013). The tool contains 30 items and 3 factors which are subject-centred curriculum design orientation, problem-centred curriculum design orientation and student-centred curriculum design orientation. When reliability analyses were conducted for the scale, following coefficients have been obtained for factors: Subject-centred curriculum design orientation is 0.89 ; student-centred curriculum design orientation is 0.89 ; problem-centred curriculum design orientation is 0.87 . Besides, the general reliability coefficient value for the scale was found to be 0.94 . In the present study, $\alpha$ coefficients have been determined to be $.86, .84$ and .80 for Subject-centred curriculum design orientation, student-centred curriculum design orientation and problem-centred curriculum design orientation, respectively.

\section{Data Analysis}

Kolmogorov-Smirnov test was used to determine whether the data followed normal distribution and as a result it was found that the data followed normal distribution as the scores obtained from teachers' views regarding curriculum design orientation preferences are greater than $\mathrm{p}>$.05. Arithmetic mean $(\bar{x})$, independent samples t- and one-way ANOVA were used during the data analysis. In addition, Lsd test was conducted so as to determine among which groups the differences have been observed.

\section{Results and Recommendation}

Upon examining the research results, the average score of student-centred curriculum design orientation factor has been found to be "totally agree". Moreover, teachers had a moderate level of subject-centred curriculum design orientation preferences whereas they"agree" about curriculum design orientation preference concerning problem-centred curriculum design. Teachers' curriculum design orientation preferences do not significantly differ in terms of both the whole scale and its subscales. On the other hand, it was not found a significant difference among teachers' curriculum design orientation preferences depending upon educational status. However, teachers' curriculum design orientation preferences differ in terms of subject-centred curriculum design. Difference was found in favor of teachers who have 20 years and over occupational seniority compared to those who have 6-10 years and 20 years and over, 11-15 years and 20 years and over, 16-20 years and 20 years and over. The fact that teachers with 20 years and over seniority prefer subject-centred curriculum design is seen as a shortcoming in the education system that is dominated by constructivist educational approach; therefore, in-service training courses may be organized. It may be wise to emphasize the significance of learner and problem-centred curriculum design orientation preference in effective learning.

Teachers' education philosophy plays a significant role in curriculum design orientation preferences. In this regard, prospective teachers should be trained by institutions where teachers are raised according to progressive educational philosophy. This study aims to determine teachers' curriculum design orientation preference. A qualitative study may be carried out in order to reveal the reasons for teachers' curriculum design orientation preference. Various studies related to the curriculum design orientation preference in terms of branch may be conducted. 